\title{
シリカゲルを用いたマトリックス固相分散法と高速液体クロマト グラフィーによる畜産食品中のサルファ剂の定量
}

(平成 5 年 12 月 10 日受理)

\author{
田 村 博* 世取山 守* \\ 黒崎かな子* 篠 原 信 勝*
}

\section{High Performance Liquid Chromatographic Analysis of Sulfonamides in Livestock Products Using Matrix Solid-Phase Dispersion (MSPD) Method with Silica Gel}

\author{
Hiroshi Tamura, Mamoru Yotoriyama, Kanako Kurosaki \\ and Nobukatu SHINOHARA \\ (Food Division, Tochigi Prefectural Institute of Public Health: \\ 4-9-7, Yonan, Utsunomiya-shi, Tochigi 320, Japan)
}

\begin{abstract}
The MSPD method with silica gel (Silica Gel-MSPD) was developed for the extraction of sulfonamides in livestock products. Residual sulfonamides such as sulfameradine (SMR), sulfadimidine (SDD), sulfamonomethoxine (SMM), sulfadimethoxine (SDM) and sulfaquinoxarine (SQO) were extracted from chicken muscle tissue, yolk and pork muscle tissue. A sample $(0.5 \mathrm{~g})$ was mixed with $0.7 \mathrm{~g}$ of silica gel and $1.5 \mathrm{ml}$ of acetonitrile, and the mixture was dried, washed with hexane and eluted with methanol or tetrahydrofuran (THF). An aliquot of the methanol or THF solution was subjected to HPLC for the determination of each sulfonamide. The recoveries of sulfonamides added to the chicken, yolk and pork were 78.1 to $93.1 \%, 74.6$ to $86.2 \%$ and 69.6 to $87.1 \%$, respectively. The limits of detection for the proposed method were $0.01 \mathrm{ppm}$ for SMR and SDD, $0.02 \mathrm{ppm}$ for SMM and $0.04 \mathrm{ppm}$ for SDM and SQO.

In order to confirm the utility of the proposed method, analyses of commercial products were performed, and the result was compared with that obtained by MSPD with ODS. Consequently, $0.94 \mathrm{ppm}$ of SMM and $0.99 \mathrm{ppm}$ of SDM were detected in two samples of pork muscle by the proposed method, whereas the values detected by using ODS were 0.81 and 0.56 ppm, respectively.
\end{abstract}

(Received December 10, 1993)

Key words: シリカゲル silica gel; マトリックス固相分散 matrix solid-phase dispersion (MSPD); サルファ棛 sulfonamides; 高速液体クロマトグラフィー high performance liquid chromatography (HPLC)

\section{1.はじめに}

食肉, 魚肉中のサルファ剂を含む合成抗菌剂の多成分 同時分析法には，ガスクロマトグラフィー $(\mathrm{GC})^{1)}, \mathrm{GC}$ 質量分析計 $(\mathrm{GC} / \mathrm{MS})^{21}$, 高速液体クロマトグラフィー $(\mathrm{HPLC})^{3 / \sim 6)}, \mathrm{HPLC} / \mathrm{MS}^{7}$ ，超臨界抽出法8)などが用いら れている.

これらの分析法の前処理操作には，液-液分配法によ

\footnotetext{
* 栃木県衛生研究所：干320 栃木県宇都宮市陽南 4-9-7
}

るクリーンアップ, ミニカートリッジなどを用いた固相 抽出法がある. いずれの方法も多数の機器, 多量の有機 溶媒を用いて抽出, クリーンアップを行い, 機器分析に 供するのが一般的である. 一方, Long らは, 新しい前処 理法として $\mathrm{C}_{18}$ を用いた matrix solid phase dispersion method $^{91.10)}$ (以下 ODS-MSPD 法)により, 牛乳 ${ }^{11}$ や豚 肉中 ${ }^{12)}$ の 8 種類のサルファ剤を定量した. また, Reimer らは, 魚肉中の 7 種類の合成抗菌剂の抽出にこの方法を 応用した ${ }^{13)}$. これらの方法は, 用いる機器, 溶媒ともに 


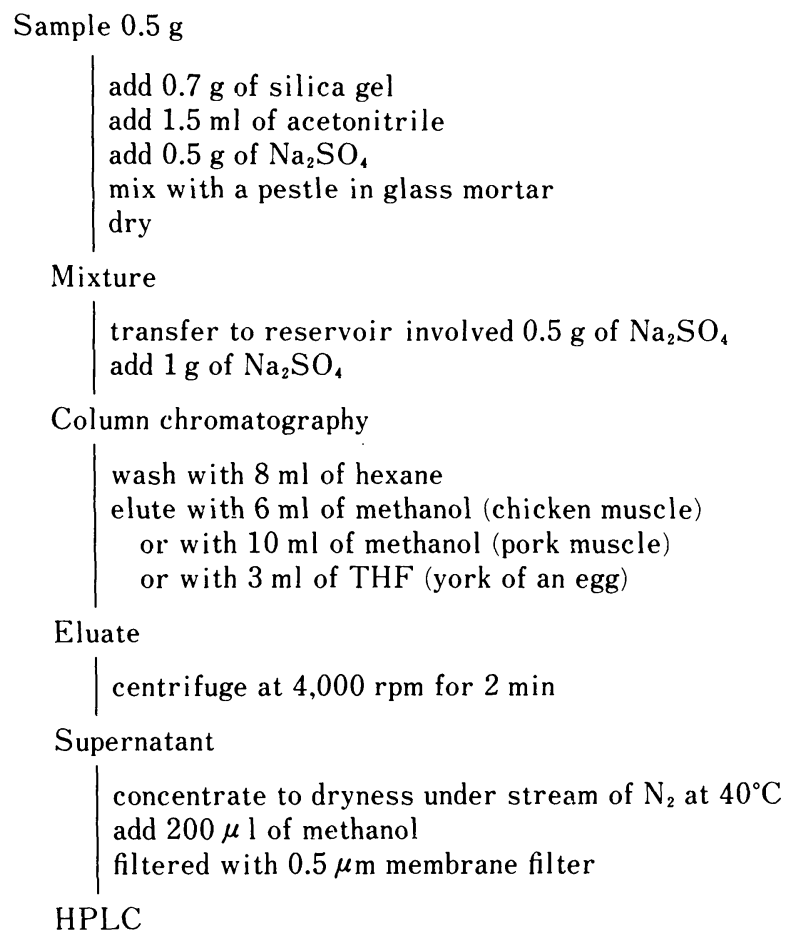

Scheme 1. Analytical procedure by MSPD method with silica gel for the determination of sulfonamides in chicken muscle tissue, pork muscle tissue and york of an egg

少なく，簡便かつ迅速に検査を行える方法である，そこ でここれらの ODS-MSPD 法を追試するとともに，著者 らは固相に少量のアセトニトリルを添加したシリカゲル を用いることにより, 鶏肉, 鷄卵黄及び豚肉中のサルフ ア剂を更に高い効率で精度良く抽出できる前処理方法 （以下シリカゲル-MSPD 法）在見いだしたので, 報告す る.

\section{2. 実験方法}

\section{1 試料}

標準添加用試料として，彩肉及び豚肉は市販品の筋肉 をぺースト状にし，小分けし，冷涷保存 $\left(-20^{\circ}\right.$ 以下) し たものを分析時に解凍して用いた。市販鵎卵は卵黄部分 を分取して用いた。

市場調查用の試料として, 鶏肉, 舀卵黄及び豚肉は市 販品を標準添加用試料と同様に処理し，直ちに分析に供 した。また，埼玉県衛生研究所より既知濃度の豚肉を譲 り受けた。

\section{2 試薬}

アセトニトリル及びメタノールは Merk 社製 HPLC 用を，テトラヒドロフラン (THF) は和光純薬工業(株) 製 HPLC 用を，へキサンは和光純薬工業(株)特級をそ れぞれ用いた。シリカゲルはVarian 社製 SI 40UM Part No. 1221〜3001 を用いた。

\section{3 器具}

リザーバー（プラスチック製注射筒）はV Varian 社製 Bond Elut Reservoir（フリット付き， $8 \mathrm{ml}$ ), ガラス乳 鉢は外径 $90 \mathrm{~mm}$ のものを用いた。

\section{4 標準試薬}

スルファメラジン (SMR), スルファジミジン (SDD) はシグマ社製、スルファモノメトキシン (SMM), スルフ アジメトキシン (SDM), スルファキノキサリン (SQQ) は, 食品衛生検査機関協議会より購入した。 5 種類のサ ルファ剤を $10 \mathrm{mg}$ 精ひょうし,メタノールでそれぞれ 正確に $100 \mathrm{ml}$ に調製し，標準原液として冷藏庫に保管 した。これらを適宜混合, メタノールで希积し, 標準液 として実験に供した。

\section{5 抽出操作}

抽出操作を Scheme 1 に示した. ガラス乳鉢に試料 $0.5 \mathrm{~g}$ を量りとり, シリカゲルを $0.7 \mathrm{~g}$ 加えた. 添加回収 実験を行うときは, $10 \mu \mathrm{l}$ の標準溶液を試料の上に添加 し，1２分放置した. 更にアセトニトリル $1.5 \mathrm{ml}$, 無水 硫酸ナトリウム $0.5 \mathrm{~g}$ を加え, 均一になるまで乳棒です りつぶした。乾燥して乳鉢の内壁が白くなるまですりつ ぶし続けた。 得られた混合物を, あらかじめ約 $0.5 \mathrm{~g}$ の 無水硫酸ナトリウムを入れたリザーバーに移した。混合 物の上に更に約 $1 \mathrm{~g}$ の無水流酸ナトリウムを加え, アダ 


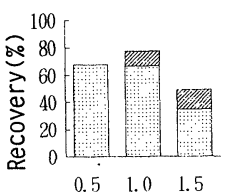

C
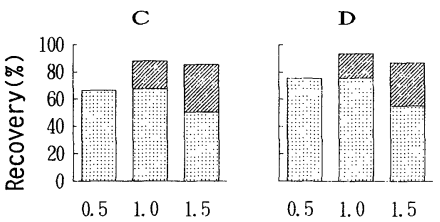

$0.5 \quad 1.0 \quad 1.5$

Methanol ( $\mathrm{ml}$ )

Fig. 1. Influence of methanol content in matrix solid-phase mixture for recovery

A: SMR; B: SDD; C: SMM; D: SDM; E: SQO

sulfonamides detected from

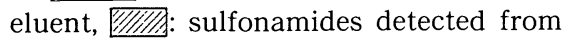
wash

プターを介してプランジャー付きのガラス注射器に取り 付けた. $n$-ヘキサン $8 \mathrm{ml}$ を $10 \mathrm{ml} / \mathrm{min}$ 程度で通し, 洗 浄した。 シリカゲルに保持されたサルファ剂は, 鶏肉に あってはメタノール $6 \mathrm{ml}$ ，鶏卵黄にあっては THF 3 $\mathrm{ml}$, 豚肉にあってはメタノール $10 \mathrm{ml}$ を $30 \mathrm{ml} / \mathrm{min}$ 程 度で通し, 溶出した. $4,000 \mathrm{rpm}$ で 2 分間遠心分離し た. 上澄みを $40^{\circ}, \mathrm{N}_{2}$ 気流中で乾固した. 残留物をメ夕 ノール $200 \mu \mathrm{l}$ で再溶解し, $0.5 \mu \mathrm{m}$ メンブランフィルタ 一でろ過し, 万液の $10 \mu \mathrm{l}$ を HPLCへ注入した。

\subsection{HPLC 条件}

分析カラムには化学品検查協会製 L- カラム ODS (4.6 $\times 15 \mathrm{~cm})$ を使用し, 溶離液にアセトニトリル $-1 \%$ 酶酸 (18:82) を用い, カラム温度 $40^{\circ}$, 流速 $1 \mathrm{ml} / \mathrm{min}$ で送 液し, 日本分光(株)製 $875 \mathrm{UV}$ を用いて $272 \mathrm{~nm}$ で測定 した.

\section{3. 結果及び考察}

\section{1 残留溶媒之回収率}

抽出溶媒が固相一試料混合物中に残留した場合の, 回 収率に与える影響について検討した結果を Fig. 1 に示 した．抽出溶媒としてメタノールを用い，ガラス乳鉢で 約 1 分間混合した後, そのまま乾燥せずにリザーバーに 移し, 洗浄, 溶出した時の回収結果である. メタノール 量を増加させると, 洗浄液中に見いだされるサルファ剤 の量む増加した。これによって各サルファ剤の回収率は 著しく減少した。すすなお, 固相一試料混合物中に残留す るメタノールは, 洗浄時にサルファ剤を一部溶出し, そ の量はメタノール量の増加に伴い増加した.このこと は, 試料と固相を混合するときは，抽出溶媒を完全に除 去する必要があることを示唆している.

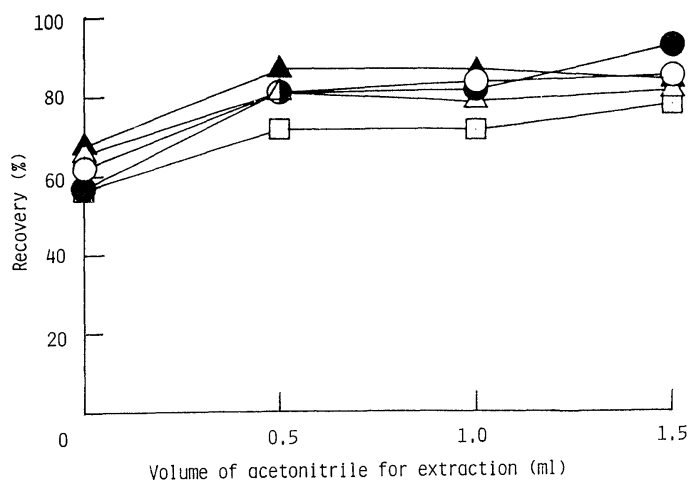

Fig. 2. Effect of acetonitrile volume on recovery

$$
\begin{aligned}
& \text { O: SMR; ๑: SDD; } \triangle \text { : SMM; } \mathbf{A}: \mathrm{SDM} ; \square: \\
& \text { SQO }
\end{aligned}
$$

\section{2 抽出溶媒の検討}

試料をシリカゲルと混合するときに用いる抽出溶媒を 選択するために，それぞれ $1.5 \mathrm{ml}$ のメタノールとアセ トニトリルを用いて添加回収実験を行った。抽出溶媒 は, 先の結果から, 試料, シリカゲル, 抽出溶媒の混合 物を乾燥するまですりつぶすことによって除去し, 抽出 操作に供した. 本項以降の検討についても同様である. メタノールを用いた場合の回収率は $61.7 \%(\mathrm{SDM})$ ～ 68.5\% (SMR) であったのに対し，アセトニトリルを用 いた結果は, 67.1\% (SMM)〜 74.6\% (SMR, SDD) と, メ タノールを用いた結果を 6〜9\% 程度上回ったため，ア セトニトリルを抽出溶媒として用いた.

抽出溶媒の最適な量を求めるために，それぞれの溶媒 量において添加回収実験を行った結果を Fig. 2 に示し た。アアセトニトリルを使用せず抽出した場合の回収率は $60 \%$ 前後であったが, 再現性が悪かった。抽出溶媒を用 いないためサルファ剂が局所的に保持され，すりつぶし の程度によって洗浄時の消失を高め, 再現性を悪化させ たあのと考えられる.アセトニトリル量 $0.5 \mathrm{ml}$ におい て SMR と SDD の回収率は $80 \%, S Q O$ は 70\% を示し た. アセトニトリル量の増加に伴い若干の増加傾向を示 し, SMM の回収率はアセトニトリル量 $0.5 \mathrm{ml} \sim 1.5 \mathrm{ml}$ の範囲において $80 \%$ 前後, SDM は 85\% 前後の高い回 収率が得られた。この結果から抽出に用いるアセトニト リル量を $1.5 \mathrm{ml}$ とした.

\section{3 溶出溶媒之溶出挙動の検討}

固相に保持されたサルファ剤の溶出に用いる溶媒の種 類について, メタノール, THF, エチルエーテルなどの 溶媒むしくはその混合系を用いて検討した。その結果, 鶏肉及び豚肉では, メタノールを使用したとき最む良い 回収率を示し, 夾雑物む少なかった。䳕卵黄では THF を用いたとき最も良い結果が得られ，他の溶媒では夾雑 
A

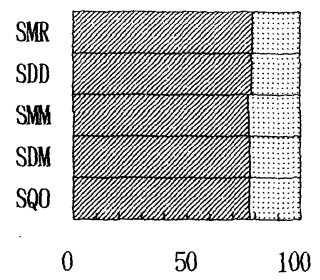

B

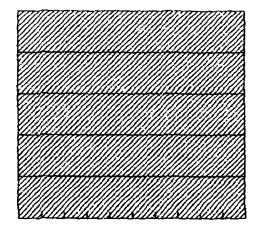

50
$\mathrm{C}$

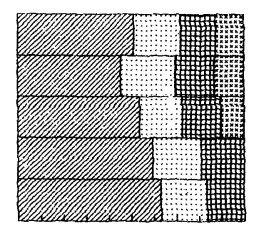

$50 \quad 100$

Fig. 3. Elution profile of sulfonamides

A: chicken muscle tissue; B: york of egg; C: pork muscle tissue

Eluents: A, C: methanol; B: tetrahydrofuran

एII : 0 2 ml; $2 \sim 4 \mathrm{ml}$;
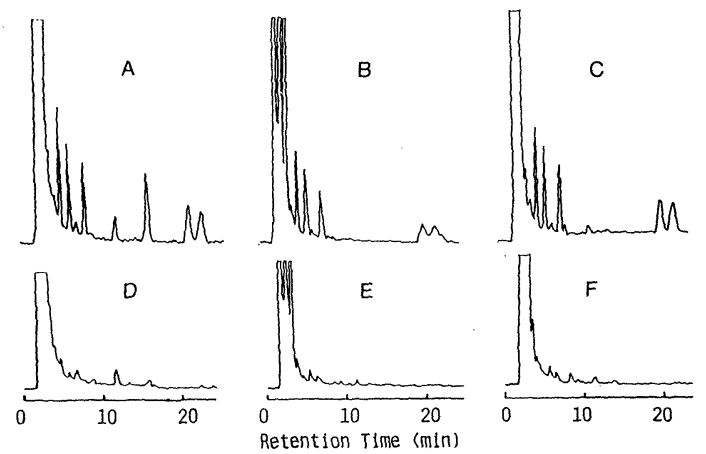

Fig. 4. Chromatograms of sulfonamides extracted from livestock products (upper row) and of controls (lower row)

A, D: chicken muscle tissue; B, E: york of an egg; C, F: pork muscle tissue

物が多く抽出された。これらの結果から，鷄肉及び豚肉 では溶出にメタノールを使用し, 鵎卵黄では THF を使 用することとした。

次に, 至適な溶出溶媒量を求めるため, 固相に保持さ れた各サルファ剤の溶出挙動を検討した結果を Fig. 3 に示した，鶏肉中のサルファ剂は,メタノールの最初の $2 \mathrm{ml}$ によって溶出された全サルファ剤の約 $80 \%$ が溶出 し, 次の $2 \mathrm{ml}$ ですべて溶出した. $4 \sim 6 \mathrm{ml}$ 以降にはサル ファ剤は見出されなかった。この結果から, 溶出に使用 するメタノールの量を $6 \mathrm{ml}$ とした．豚肉中のサルファ 剂は, 全量が溶出されるまでにメタノール $8 \mathrm{ml}$ を要し た. 8〜 $10 \mathrm{ml}$ 以降にはサルファ滖は見いだされなかっ たことから，溶出に使用するメタノール量を $10 \mathrm{ml}$ とし た. 鶏卵黄中のサルファ剂は, THF の最初の $2 \mathrm{ml}$ によ って全サルファ剂が溶出された．2〜 $4 \mathrm{ml}$ 目以降にはサ ルファ剤は見出されなかった，この結果から，溶出に使 用する $\mathrm{THF}$ 量を $3 \mathrm{ml}$ とした。

\section{4 食品への添加回収}

2.5 の方法により，5回の添加回収実験を行った結果
Table 1. Recoveries of Sulfonamides by MSPD Method

\begin{tabular}{|c|c|c|c|}
\hline & & \multicolumn{2}{|c|}{$\begin{array}{c}\text { Recovery (\%) } \\
(\text { Mean } \pm \text { S.D. }(n-1), n=5)\end{array}$} \\
\hline & & Silica gel*1 & ODS*2 \\
\hline \multirow[t]{5}{*}{ Chicken muscle } & SMR & $85.7 \pm 2.8$ & $61.4 \pm 14.2$ \\
\hline & SDD & $93.1 \pm 4.7$ & $59.2 \pm 15.1$ \\
\hline & SMM & $81.7 \pm 4.2$ & $53.2 \pm 13.7$ \\
\hline & SDM & $84.4 \pm 5.0$ & $61.4 \pm 11.0$ \\
\hline & SQO & $78.1 \pm 5.4$ & $56.2 \pm 18.6$ \\
\hline \multirow[t]{5}{*}{ York of egg } & SMR & $86.2 \pm 2.8$ & $52.2 \pm 1.2 .1$ \\
\hline & SDD & $74.6 \pm 4.2$ & $46.8 \pm 11.7$ \\
\hline & SMM & $83.0 \pm 2.7$ & $39.3 \pm 7.2$ \\
\hline & SDM & $85.0 \pm 4.3$ & $38.3 \pm 8.6$ \\
\hline & SQO & $84.8 \pm 4.3$ & $31.5 \pm 6.1$ \\
\hline \multirow[t]{5}{*}{ Pork muscle } & SMR & $72.4 \pm 6.9$ & $39.3 \pm 24.0$ \\
\hline & SDD & $76.1 \pm 10.3$ & $37.7 \pm 13.4$ \\
\hline & SMM & $69.6 \pm 6.0$ & $38.5 \pm 13.6$ \\
\hline & SDM & $87.1 \pm 14.3$ & $39.2 \pm 14.3$ \\
\hline & SQO & $73.1 \pm 6.9$ & $30.1 \pm 11.1$ \\
\hline
\end{tabular}

*1: MSPD with silica gel; *2: MSPD with $\mathrm{C}_{18}$

をTable 1 の左側に示し, 代表的なクロマトグラムを Fig. 4 に示した. 添加されたサルファ剂は, 共存物質に ほとんど妨害されずに分離された。

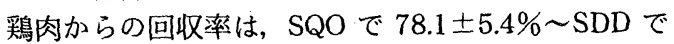
$93.1 \pm 4.7 \%$, 鶏卵黄では SDD で $74.6 \pm 4.2 \%$ SMR で $86.2 \pm 2.8 \%$ と高い値を示した. 豚肉少らの回収率は, SMM で $69.6 \pm 6.0 \%$ SDM で $87.1 \pm 14.3 \%$ であり, SDD と SDM の再現性が悪かった. この方法における検 出限界は, $\mathrm{S} / \mathrm{N}=3$ として算出すると, それぞれ SMR: 0.01, SDD: 0.01, SMM: 0.02, SDM: 0.04, SQO: 0.04 ppm であった.

\subsection{ODS-MSPD 法との比較}

抽出溶媒を用いない Long らの ODS-MSPD 法 ${ }^{12)}$ でも 添加回収実験を行った．その結果を Table 1 の右側に併 
せて示した．回収率 70\% 程度を示す結果も得られたが, 一方では $20 \%$ 程度に留まることああり，平均すると， $30.1 \pm 11.1 \%$ (pork-SQO) $61.4 \pm 14.2 \%$ (chicken $\mathrm{SMK}, \mathrm{SDM})$ と低く，再現性も全体に悪かった，原因と しては，先に述べたとおり，抽出溶媒を用いないために サルファ剂が局所的に保持され，すりつぶしの程度によ って洗浄時の消失を高め, 再現性を悪化させたものと考 えられる.

\section{6 市場調査の結果}

シリカゲル-MSPD, ODS-MSPD 両法で市場調査を行 った，鶏肉，鶏卵黄及び豚肉合わせて 18 検体中，豚肉 2 検体からサルファ剂が検出された．シリカゲル-MSPD 法による検出值は SDM が $0.99 \mathrm{ppm}, \mathrm{SMM}$ が 0.94 ppmであったのに対し, ODS-MSPD 法による検出值 は，それぞれ 0.56, $0.81 \mathrm{ppm}$ といずれも下回った。この 市場調查結果によって，シリカゲル-MSPD 法による添 加回収実験結果の信頼性が実証された。固相と試料だけ を混合する ODS-MSPD 法では，サルファ剂は固相と試 料の直接接触によってのみ抽出されるのに対して, シリ カゲル-MSPD 法では，アセトニトリルが存在すること によって有機溶媒抽出の効果が付加される. サルファ剂 はアセトニトリルに抽出され, 均一に分散し, シリカゲ ルに均等に保持されると推測される。固相と試料を直接 混合して抽出しようとするときは，有機溶媒を併用する ことが重要であることが明らかとなった。

\section{4. まとめ}

鶏肉, 鶏卵黄及び豚肉中の 5 種類のサルファ阂 ( $\mathrm{SMR}$, $\mathrm{SDD}, \mathrm{SMM}, \mathrm{SDM}, \mathrm{SQO})$ は, アセトニトリルとともにシ リカゲルと直接混合するシリカゲル-MSPD 法によっ て，効率よく抽出されることが認められた。固相之試料 を直接混合してサルファ剂を抽出しようとするときは, 有機溶媒を併用しなければ，高い抽出効率は期待できな いことが明らかとなった。

このシリカゲル-MSPD 法は，使用する溶媒量が少な い方法である. また，試料全量をりザーバー内に充てん
する上に，アセトニトリルによる溶媒効果も付加するこ とによって極めて高い抽出効果が得られた. 更にシリカ ゲルを用いることで, ODS を用いる従来の MSPD 法に 比較してランニングコストも低く抑えられた。 これらの 利点を生かして, 現在, 他の合成抗菌剤, 抗生物質, 食 品添加物など八の応用についても検討中である.

謝 辞

試料を提供してくださった埼玉県衛生研究所堀江正一 博士に深謝致します.

\section{文献}

1) Manuel, A. J., Steller, W. A.: J. Assoc. Off. Anal. Chem. 64, 794 799 (1981).

2) Mooser, A. E., Koch, H.: ibid. 76, 976 982 (1993).

3) 堀江正一, 斉藤貢一, 星野庸二, 能勢憲英, 浜田尚樹, 中 澤裕之: 食衛誌. 31, 171 176 (1990).

4) Horie, M., Saito. K., Nose, N., Nakazawa, H.: J. Assoc. Off Anal. Chem. 75, 786 789 (1992).

5) Horii, S., Momma, C., Miyahara, K., Maruyama, T., Matsumoto, M.: ibid. 73, 990 992 (1990).

6) 姫井るり子, 小出圭子, 辻功, 山本誠司, 垭江正一, 鈴木澄子, 中澤裕之：食衛誌。34, 392 397 (1993).

7）堀江正一, 斉藤貢一, 星野庸二, 能勢憲英, 寺 正成, 楿 和氐陽, 中澤裕之, 山根靖弘：衛生化学 36, 283 289 (1990).

8) Ezzell, J. L., Richter, B. E.: J. Chromatogr. Sci. 31, 162 169 (1993).

9) Barker, S. A., Long, A. R.: J. Liquid Chromatogr. 15, 2,071 2,089 (1992).

10) Walker, C. C., Lott, H. M., Barker, S. A.: J. Chromatogr. 642, 225 242 (1993).

11) Long, A. R., Short, C. R., Barker, S. A.: ibid. 502, 87 94 (1990).

12) Long, A. R., Hsieh, L. C., Malbrough, S., Short, C. R., Barker, S. A.: J. Agric. Food Chem. 38, 423 426 (1990).

13) Reimer, G. J., Suarez, A.: J. Assoc. Off. Anal. Chem. 75, 979 981 (1992). 